\title{
THE SUCCESSES AND CHALLENGES FOR THE EUROPEAN COURT, SEEN FROM THE OUTSIDE
}

\author{
Laurence R. Helfer*
}

This piece is adapted from an address delivered to a conference sponsored by the Council of Europe and PluriCourts ${ }^{1}$ on The Long-Term Future of the European Court of Human Rights ${ }^{2}$ in Oslo, Norway on April 7, 2014.

This post addresses the successes and challenges for the European Court of Human Rights (ECtHR), as seen from the outside. It draws upon my co-authored research on human rights systems outside of Europe ${ }^{3}$ to explain how these systems have responded to some of the same challenges now facing the Council of Europe and the ECtHR. My main contention is that international human rights courts, wherever they are located, require sustained political and material support if they are to thrive and grow over time.

I illustrate this argument with examples from the Inter-American ${ }^{4}$ and African courts of human rights ${ }^{5}$ and from lesser-known courts of sub-regional legal systems in Africa-the Economic Community of West African States (ECOWAS), ${ }^{6}$ the East African Community (EAC) ${ }^{7}$ and the Southern African Development Community (SADC). ${ }^{8}$ The judges of these courts often look to ECtHR case law for guidance. They are also aware of the high level of political and material support for the Strasbourg supervisory system. Just as these courts have drawn inspiration from the ECtHR, so too those who will shape the Court's long-term future should consider both the achievements and the challenges that these regional and sub-regional systems have faced. ${ }^{9}$ In describing these positive and negative developments, I will focus on three issues- the evolution of

* Harry R. Chadwick, Sr. Professor of Law and Co-director of the Center for International and Comparative Law at Duke University. He has authored more than seventy publications relating to his diverse research interests, which include international buman rights, treaty design, international adjudication, and interdisciplinary analysis of international law and institutions

Originally published online 14 May 2014. Cross-posted on EJIL:TALK!.

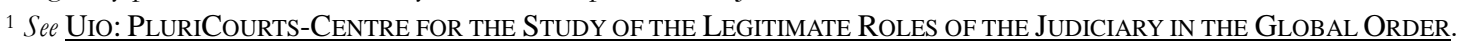

2 Council of Europe, The Long-Term Future of the European Court of Human Rights, MultiRights Annual Conference, Oslo, Norway, Apr. 7-8 2014.

${ }_{3}^{3}$ Duke Law, Helfer Project Examines the Evolution of International Human Rights Courts in Africa, DUKE LAw NEws (Sept. 11, 2013).

4 See INTER-AMERICAN COURT OF Human RightS.

5 See African Court on Human and People's Rights.

6 See COMMUNity COURT OF JUSTICE - ECOWAS.

7 See The EAST African COURT OF Justice.

8 See SOUTHERn AFrican DEVELOPMENT COMMUNiTY.

${ }^{9}$ Karen J. Alter et al., A New International Human Rights Court for West Africa: The ECOWAS Community Court of Justice, 107 AJIL 737 (2013).

ASIL and Laurence R. Helfer (C) 2014 
human rights jurisprudence, the politics of compliance with court judgments, and government resistance and backlash.

The evolution of human rights jurisprudence. The innovative doctrines and principles pioneered by judges in Strasbourg ${ }^{10}$ are alive and well in other human rights systems. Interpretive tools such as the evolutionary nature of human rights, the presumption that rights must be practical and effective, the creative and strategic approach to remedies, and cross-fertilization of legal norms are commonplace in the case law of all regional and sub-regional courts. For example, Inter-American judges have applied these doctrines in several types of cases, including the obligation to investigate, prosecute and punish the perpetrators of past human rights violations, ${ }^{11}$ the prohibition of amnesty for such violations, ${ }^{12}$ the rights of LGBT persons, ${ }^{13}$ and affirmative measures to combat violence against women. ${ }^{14}$ Mtikila v. Tanzania, ${ }^{15}$ the first merits judgment of the African Court of Human and Peoples' Rights decided in 2013, analyzes the decisions of the other two regional human rights courts and the U.N. Human Rights Committee to support its conclusion that a ban on independent candidates standing for election violates the African Charter. Among the most striking examples of creative legal interpretation appear in the case law of the East African Court of Justice ${ }^{16}$ and the SADC Tribunal. ${ }^{17}$ The judges of those courts have cited references to human rights, the rule of law and good governance in the principles and objectives clauses ${ }^{18}$ of treaties establishing the economic communities to justify expanding their jurisdiction to include human rights. ${ }^{19}$

The politics of compliance with international court judgments. These capacious interpretations have broadened the scope and reach of international human rights law. But they have also engendered significant compliance challenges. All other things equal, the more expansive and far-reaching remedies a court requires, the greater the likelihood of delay or resistance in implementing its judgments-in terms of political will, capacity, and commitment of resources.

The Inter-American Court has the most ambitious approach to remedies, ${ }^{20}$ often specifying in exquisite detail the measures states must adopt. Governments have responded by implementing the easier and less politically costly remedies, with the result that partial compliance with the Inter-American Court's judgments

${ }^{10}$ Steven Greer, The Interpretation of the European Convention on Human Rights: Universal Principle or Margin of Appreciation?, 3 UCL HUMAN RTS. REV. 1 (2010).

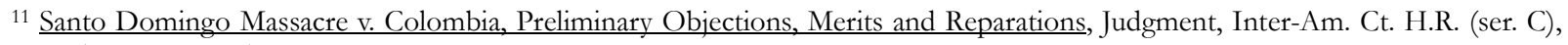
No. 259 (Nov. 30, 2012).

${ }^{12}$ Gelman v. Uruguay, Merits and Reparations, Judgment, Inter-Am. Ct. H.R. (ser. C), No. 221 (Feb. 24, 2011).

13 Atala Riffo \& Daughters v. Chile, Request for Interpretation of Judgment on Merits, Reparations and Costs, Judgment, Inter. Am. Ct. H.R. (ser. C), No. 254 (Nov. 21, 2012).

${ }^{14}$ González et. al. (“Cotton Field”) v. Mexico, Preliminary Objection, Merits, Reparations, and Costs, Judgment, Inter. Am. Ct. H.R. (ser. C), No. 205 (Nov. 16, 2009).

${ }^{15}$ Christopher R. Mtikila v. The United Republic of Tanzania (Application No. 11/2011), African Ct. on Human \& Peoples' Rights (2011).

${ }^{16}$ Katabazi and 21 Others v. Sec'y Gen. of the East African Community \& Another, Judgment, (No.1/2007), E. African Ct. of Justice (Nov. 1, 2007).

17 See Case Law, Southern African Development Community Tribunal.

${ }_{18}$ Treaty Establishing the East African Community, ch. 2: Establishment and Principles of the Community, art. V, art. VI, Nov. 30, 1999.

${ }^{19}$ Mike Campbell (Pvt) Ltd and Others v. Republic of Zimbabwe, Judgment, (No. 2/2007), Southern African Development Community Trib. (Nov. 28, 2008).

20 Tom Antkowiak, Remedial Approaches to Human Rights Violations: The Inter-American Court of Human Rights and Beyond, 46 COLUM. J. TRANSNAT'L. L. 351 (2008). 
is now commonplace. ${ }^{21}$ Human rights courts in Africa are more circumspect, reflecting the fact that these nascent tribunals are have fewer government or civil society allies 22 to advocate for compliance with more ambitious remedial orders. In the Mtikila case, ${ }^{23}$ for example, the African Court directed Tanzania "to take constitutional, legislative and all other necessary measures within a reasonable time to remedy the violations found by the Court and to inform the Court of the measures taken." It did not, however, indicate which measures were necessary. A similar approach appears in the 2012 judgment of the ECOWAS Court in SocioEconomic Rights and Accountability Project v. Nigeria, ${ }^{24}$ a case involving environment damage by multinational oil companies in the Niger Delta. The Court found Nigeria responsible for failing to regulate the companies that had despoiled the area, but it rejected a demand for U.S. \$1 billion as impractical. Instead, the judges ordered the government to "take all measures" to restore the environment, prevent future damage, and hold the perpetrators accountable-without, however, specifying how the government was to achieve these goals.

Government resistance and backlash. Expansive legal interpretations and creative remedies are natural outgrowths of maturing human rights systems in which judges regularly apply international law to a diverse array of factual circumstances. Yet as courts have issued more rulings that touch on politically sensitive topics, they have increasingly encountered overt-and occasionally strident-opposition from some states. Adverse reactions include reductions in funding (an ongoing challenge in the Inter-American system ${ }^{25}$ ); restructuring the court (such as the creation of the EACJ Appellate Division ${ }^{26}$ following a controversial 2005 decision $^{27}$ ); and politicizing judicial appointments. More extreme responses include overt noncompliance to signal a government's displeasure with specific rulings; unilateral treaty withdrawals ${ }^{28}$ (most recently, Venezuela's 2013 denunciation of the American Convention ${ }^{29}$ ); threats to create a rival human rights regime (a possibility being explored by several left-leaning South American countries $\left.{ }^{30}\right)$; and even suspending the court and stripping its jurisdiction to hear complaints from private litigants (a rebuke of the SADC Tribunal spearheaded by Zimbabwe in 201131).

Implications for the long-term future of the ECtHR. What lessons do these developments outside of Europe hold for the ECtHR's long-term future? First, the negative views recently expressed by some parliamentarians, ${ }^{32}$ political leaders, ${ }^{33}$ and national judges ${ }^{34}$ in the Brighton Declaration, ${ }^{35}$ in judicial opinions, in public speeches,

21 Alexandra Huneeus, Courts Resisting Courts: Lessons from the Inter-American Court's Struggle to Enforce Human Rights, 44 CORNELL INT'L L.J. 493 (2011).

22 See Alter et al., supra note 9.

${ }^{23}$ Reverend Christopher R. Mtikila v. The United Republic of Tanzania (Application No. 11/2011), Judgment, African Ct. on Human \& Peoples' Rights (2011).

${ }^{24}$ Serap v. Fed. Republic of Nigeria, Judgment, (No. 18/12), Community Court of Justice of ECOWAS (Dec. 14, 2012).

${ }^{25}$ Duane W. Krohnke, Failed Efforts to Weaken the Inter-American Human Rights System Under the Guise of Reform, DWKCOMMENTARIES (Mar. 26, 2013).

26 Appellate Division, East African Court of Justice, EAST African COMMunity.

${ }^{27}$ The East African Law Society and 4 Others v. The Attorney General of the Republic of Kenya and 3 Others, Judgment, (No. 3/2007), East African Ct. of Justice (2007).

${ }^{28}$ Laurence R. Helfer, Overlegalizing Human Rights: International Relations Theory and the Commonwealth Caribbean Backlash Against Human Rights Regimes, 102 Colum. L. Rev. 1832 (2002).

${ }^{29}$ Diego Germán Mejía-Lemos, Venezuela's Denunciation of the American Convention on Human Rights, 17 ASIL INSIGHTS (2013).

30 Javier Ciurlizza, Searching for an Exit: Latin America and Venezuela, In PURSuit OF PeACE Blog, InT'L CRISIS Group (Mar. 11, 2014).

${ }^{31}$ Laurie Nathan, The Disbanding of the SADC Tribunal: A Cautionary Tale, 35 Hum. RTS. Q. 870 (2013).

32 Dominic Raab, Strasbourg in the Dock: Prisoner Voting, Human Rights \& the Case for Democracy (2011).

33 Press Ass'n, Cameron: I'd Withdraw from Human Rights Convention 'to Keep UK Safe', THE Guardian (Sept. 29, 2013).

${ }^{34}$ David Barrett, 'Strasbourg not superior to British courts' Says Former Senior Judge, TELEGRAPH (Dec. 4, 2013). 
and in academic writings may signal to the ECtHR the need for caution when expansively interpreting the Convention and fashioning remedies. This is not to suggest that the Court will abandon or significantly narrow the jurisprudential principles that it has so carefully developed. Rather, I foresee that these principles will be supplemented by other nuanced doctrines that enable the ECtHR to fine-tune the deference given to national decision-makers ${ }^{36}$ depending upon how faithfully they apply the Convention ${ }^{37}$-as interpreted in Strasbourg-within their respective national legal orders.

Second, the positive feedback loop that induces states to implement ECtHR judgments is in danger of stalling. Over the last few decades, this virtuous circle has created a culture of compliance ${ }^{38}$ that views adherence to Strasbourg judgments as the norm and noncompliance as the problematic exception that can rightfully be challenged by other governments and civil society groups. As the Court has become more skilled at identifying systematic human rights violations, ${ }^{39}$ however, the delays in compliance ${ }^{40}$ by states responsible for those violations have lengthened and are becoming endemic in some countries. In addition to the ongoing harm to the thousands of individuals whose rights continue to be violated, this trend risks generating a vicious circle in which government officials point to public criticisms of the Court and compliance delays in other states to justify noncompliance in their own jurisdictions and to legitimize criticism of those who advocate for adherence to ECtHR rulings.

A final implication of the challenges to human rights adjudication outside of Europe relates to the possibility of a more widespread backlash against the ECtHR. Russia's recent military and political interventions in the Ukraine, the tens of thousands of applications pending against Russia, ${ }^{41}$ and the government's "traditional values" campaign in the U.N. Human Rights Council ${ }^{42}$ and at home ${ }^{43}$ are ominous signs of Russia's growing dissatisfaction with the European Convention and the ECtHR. In fact, it is not beyond contemplation that Russia will create a rival Eurasian human rights regime comprised of a few allies in Eastern Europe and former Soviet republics in central Asia. The laws and institutions of such a system may superficially resemble those of the Council of Europe. In reality, however, they would be much weaker. A Eurasian human rights mechanism need not involve Russia's withdrawal from the European Convention-at least not initially. But even if the country remains nominally subject to the ECtHR's jurisdiction, its officials can point to the competing decisions of Eurasian human rights bodies to justify and legitimize noncompliance with the Strasbourg Court's judgments.

In sum, the progressive evolution of international human rights laws and institutions should never be taken for granted - even in Europe. To the contrary, these laws and institutions need to be actively nurtured and supported. Such nurturing and support includes providing judges and registry lawyers in Strasbourg with the

35 Council of Europe High level Conference on the Future of the European Court of Human Rights, Brighton, U.K., Apr. 19-20, 2012, Brighton Declaration (Apr. 2012).

${ }^{36}$ Laurence R. Helfer, Redesigning the European Court of Human Rights: Embeddedness as a Deep Structural Principle of the European Human Rights Regime, 19 EuR. J. INT'L L. 125 (2008).

${ }^{37}$ Laurence R. Helfer, The Burdens and Benefits of Brighton, 1 ESIL REFLECTIONS (June 8, 2012).

${ }^{38}$ Comm. on Legal Affairs and Human Rights, Report Guaranteeing the Authority and Effectiveness of the European Convention on Human Rights, EUR. PARL. Ass. AS/Jur (2011) 44 (Nov. 4, 2011).

39 See African Court on Human ANd People's Rights.

40 Elisabeth Lambert Abdelgawad, The Execution of the Judgments of the European Court of Human Rights: Towards a Non-coercive and Participatory Model of Accountability, 69 ZAÖRV 471 (2009).

41 See Russia, Press Country Profile, European Ct. of Human Rights (last updated July 2016).

42 Graeme Reid, 'Traditional Values' Code for Human Rights Abuse?, HumAn Rights WATCH (Oct. 17, 2012).

43 Paul Johnson, Homosexual Propaganda' Laws in the Russian Federation: Are They in Violation of the European Convention on Human Rights?, 3 Russian L.J. 37 (2015). 
resources needed to process the backlog of cases. It is far more important, however, to bolster the NGOs, bar associations, national judges, and academics who are the ECtHR's crucial interlocutors and compliance constituencies. These domestic actors must have the material support and the political space to continue to pressure governments to live up to the aspirations they espoused when creating what remains the world's most advanced international system for protecting human rights. 